\title{
BRINGING LIFE TO OCEAN OBSERVATION
}

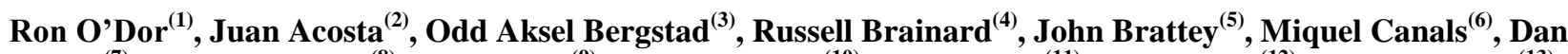 \\ $\operatorname{Costa}^{(7)}$, Kristina Gjerde ${ }^{(8)}$, John Gunn ${ }^{(9)}$, John K. Horne ${ }^{(10)}$, Katrin Iken ${ }^{(11)}$, John Kocik ${ }^{(12)}$, Brenda Konar ${ }^{(13)}$ \\ John Payne ${ }^{(14)}$, Chris Reid ${ }^{(15)}$, Bruce Robison ${ }^{(16)}$, Dirk Steinke ${ }^{(17)}$, Edward Vanden Berghe ${ }^{(18)}$
}
(1) Consortium for Ocean Leadership, 1201 New York Ave. NW, Washington, DC 20005, USA, Email: rodor@oceanleadership.org

(2) Instituto Español de Oceanografía, Madrid, Spain, Email: Juan.acosta@md.ieo.es

(3) Institute of Marine Research, Flфdevigen, N-4817 His, Norway, Email: oddaksel@imr.no

(4) National Oceanic and Atmospheric Administration, Pacific Islands Fisheries Science Center, 1601 Kapiolani Blvd., Suite 1110, Honolulu, HI 96814, USA, Email: Rusty.Brainard@noaa.gov

(5) Fisheries and Oceans Canada, PO Box 5667, St. John's, NL A1C 5X1, Canada, Email: john.brattey@dfo-mpo.gc.ca

(6) GRC Geociències Marines, Universitat de Barcelona, Spain, Email: miquelcanals@ub.edu

(7) University of California, 100 Shaffer Rd, Santa Cruz, CA. USA 95060, Email: costa@biology.ucsc.edu

(8) IUCN High Seas Policy Advisor, Konstancin-Chylice, Poland, Email: kgjerde@it.com.pl

(9) Australian Antarctic Division, Hobart, TAS 7001, Australia, Email: John.Gunn@aad.gov.au

(10) University of Washington, School of Aquatic and Fisheries Science, Box 355020, Seattle, WA 98195-5020 USA, Email: jhorne@u.washington.edu

(11) University of Alaska Fairbanks, PO Box 757220, Fairbanks, AK USA 99775-7220, Email: iken@ims.uaf.edu (12) NOAA Fisheries Maine Field Station, 17 Godfrey Drive - Suite 1, Orono, ME 04473, USA, Email: John.Kocik@noaa.gov

(13) University of Alaska Fairbanks, PO Box 757220, Fairbanks, AK USA 99775-7220, Email: bkonar@ guru.uaf.edu (14) POST, Vancouver Aquarium, P. O. Box 3232, Vancouver, British Columbia, Canada, V6B 3X8, Email: jcpayne@u.washington.edu

(15) Sir Alister Hardy Foundation for Ocean Sciences (SAHFOS), The Laboratory, Citadel Hill, Plymouth, UK, PL1 2PB, Email: pcre@sahfos.ac.uk

(16) Monterey Bay Aquarium Research Institute, 7700 Sandholdt Road, Moss Landing, CA 95039, Email: robr@mbari.org

(17) University of Guelph, 50 Stone Road East, Guelph, Ontario, Canada, N1G 2W1, Email: dsteinke@uoguelph.ca (18) Ocean Biogeographic Information System, Rutgers University, NJ, USA, Email: evberghe@iobis.org

\section{ABSTRACT}

The fourteen field projects of the Census of Marine Life (Census) have helped gather 22 million species/location references globally from the abyssal plains to the ocean surface. Some of the breakthrough technologies that make biodiversity monitoring possible now include DNA barcoding and microchips combined with standardized sampling techniques, upward looking and horizontal waveguide sonar techniques that view huge areas, use of animal-borne sensors to define oceanic habitats, and a combination of acoustic and satellite tracking techniques that allow us to reassemble species interactions in the open ocean to meet increasing demands for ecosystem-based management of ocean resources. Census' Ocean Biogeographic Information System (OBIS), which contains these records, has recently been accepted by the Intergovernmental Oceanographic Commission as a component of IODE, simplifying the process of linking biodiversity data with physical data on a global scale. OBIS contains records dating back a thousand years from the Oceans Past project and has been used to project scenarios forward in the Oceans Future project, so the feasibility of linking the physical and biological ocean is greatly enhanced. We focus on how best to implement these cross-over technologies.

\section{INTRODUCTION}

The over 2000 participants from over 80 countries involved in the Census of Marine Life (Census) have invested some $\$ 650 \mathrm{M}$ during the first decade of the $21^{\text {st }}$ century in compiling and distributing information about ocean biodiversity, identifying knowledge gaps and demonstrating new technologies for closing those gaps. This paper will attempt to summarize the achievements and conclusions from the last decade and project biological deliverables over the next decade. There are over a dozen Community White Papers that relate to this summary $[1,2,3,4,5,6,7,8,9,10,11,12,13,14$ and 15] and many additional contributions that relate to higher trophic level biology that are not well represented among the Plenary Talks, so this whole paper could be filled with citations. What follows attempts to strike a balance between the scientific inputs and some societal benefits that have been to a large extent neglected in ocean observing to date. Routine 
observing of changing biological diversity in the global ocean is difficult, but not impossible, and is highly valued by society for both commercial and conservations reasons.

The Census developed from the recognition that no country in the world had the capacity to meet its obligations under the Convention on Biological Diversity (CBD) to catalog marine species [16]. Recognizing that the CBD mandate would require continuing monitoring of diversity, Census focused on the most economical, rapid and repeatable technologies for all of its Ocean Realm habitats and how best to include biodiversity measures in routine ocean observing systems. Note that the simplified Realm and Project nomenclature in Table 1 was chosen specifically to make the invisible oceans more accessible to society. The technologies have already proved valuable for providing societal benefits in the GEO (Group on Earth Observations) and GOOS (Global Ocean Observing System) contexts [17 and 18]. Census has shown by published examples the power of modern deep sea camera systems for identifying diversity [19], of tagging and tracking technologies for distribution [4 and 9] and of sonar systems for abundance. Advanced sonars can see shrimp $3 \mathrm{~km}$ down [20] and wave-guide acoustics can count fish within a $100 \mathrm{~km}$ circle [21]. Experimental concepts have become practical tools.

Census brings its wealth of information on diversity, distribution and abundance of marine species to the Intergovernmental Oceanographic Commission (IOC) with the recent commitment for its Ocean Biogeographic Information System to become the diversity component of IODE (International Oceanographic Data and Information Exchange). Many Census projects already have ongoing commitments to provide regular ocean observations of biodiversity and habitat changes beyond the first census in 2010. The Near Shore projects have relatively simple, standardized protocols for repeated, rapid sampling of biodiversity using DNA (deoxyribonucleic acid) barcodes and chip technology, for example, monitoring coral reef biodiversity using novel environmental gene sequencing for rapid enumeration. Coastal projects can monitor the movements of commercial and conservation species in near real time and link these to changing oceanographic conditions. These habitat data collected by sensors on animal platforms, particularly in the Ice Oceans are already being integrated into ocean models and providing ground truthing for satellite imagery by Census and a suite of global projects using similar technology now being linked through www.gtopp.org. Canada and a series of global partners are committed to support the Ocean Tracking Network spin-off project as a GOOS project through 2015. Census' Central Waters and Hidden Boundries projects have been and will continue to be major information contributors to policy development for seamount fisheries, mining, etc. under the FAO (Food and Agriculture Organization of the United Nations) and Law of the Sea Convention [17 and 18]. Society has difficulty recognizing the need for knowledge about these unseen places, but science does not and has a responsibility to make every effort to spread the word. Techniques like high resolution upward-looking sonar have clear near real time monitoring potential even in the most difficult Central Ocean Realm.

\begin{tabular}{|l|l|}
\hline \multicolumn{1}{|c|}{ Realm } & \multicolumn{1}{c|}{ Field Projects } \\
\hline Human Edges & $\begin{array}{l}\text { Near Shore } \\
\text { Coral Reefs Regional } \\
\text { Ecosystems Continental } \\
\text { Shelves }\end{array}$ \\
\hline Hidden Boundaries & $\begin{array}{l}\text { Continental Margins Abyssal } \\
\text { Plains Seamounts } \\
\text { Seep and Vents }\end{array}$ \\
\hline Central Waters & $\begin{array}{l}\text { Zooplankton } \\
\text { Top Predators } \\
\text { Mid-Ocean Ridges }\end{array}$ \\
\hline Ice Oceans & Arctic Ocean Antarctic Ocean \\
\hline Microscopic Ocean & Microbes \\
\hline
\end{tabular}

Table 1. Census Simplified Realms and Projects

Key questions raised include:

1. What is an oceanic ecosystem?

2. How will global warming affect them?

3. Will biodiversity decline? Will production decline?

4. How much detail is needed to monitor biodiversity?

5. Can ecosystem-based management differentiate climate effects from fishing effects? 

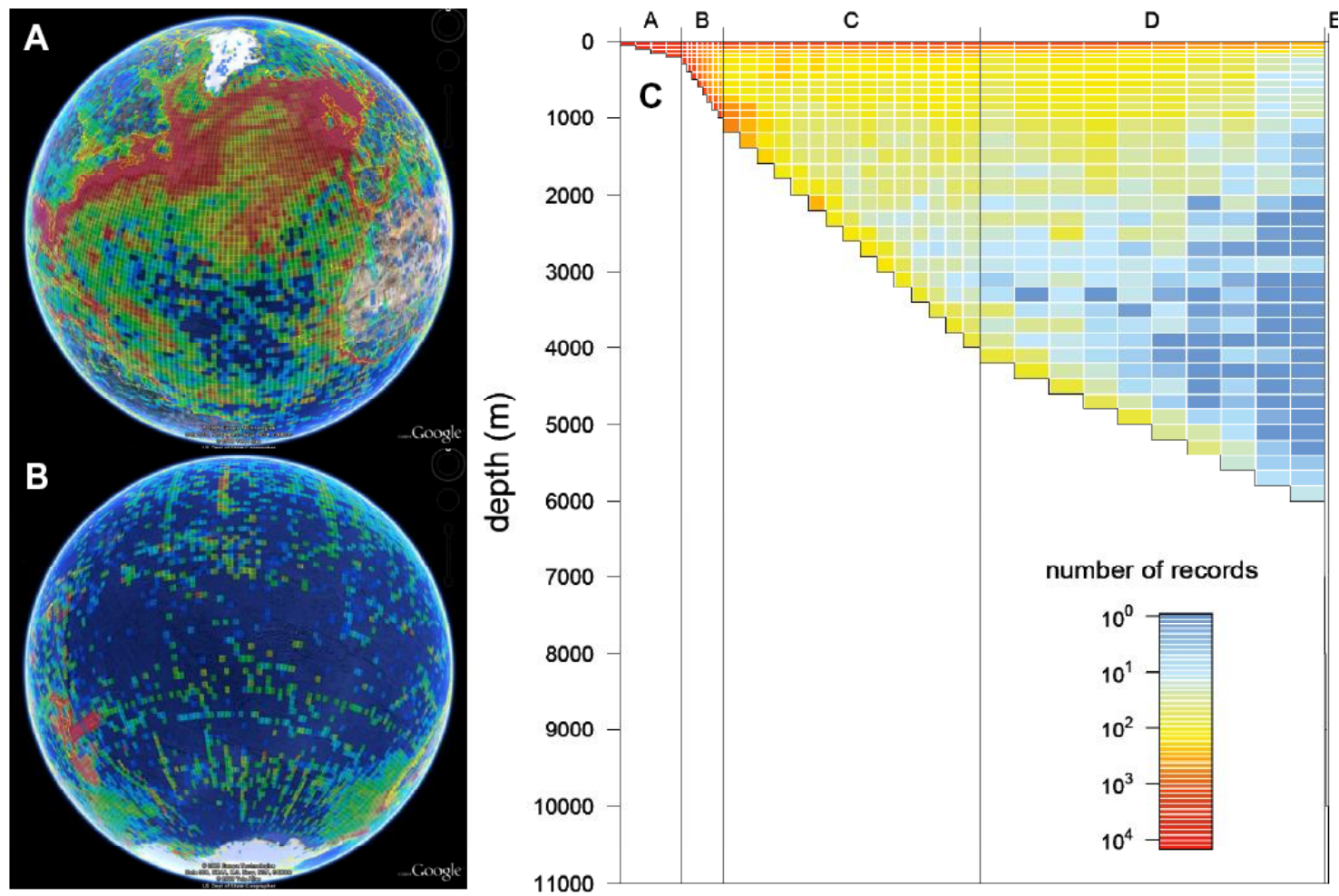

Figure 1. Distribution of the 22,000,000 species records in the Ocean Biogeographic Information System. (A) North Atlantic biodiversity index by degree square - excellent coverage. (B) South Pacific-significant but sparse coverage.

(C) Nearly all of the diversity records are for shallow water or benthos. In depth zones A-E, each large dark blue cell below 1000m represents nearly 4,000,000 cubic km of un-sampled ocean out the 1,000,000,000+ total [22].

\section{SOME ANSWERS FROM COMMUNI'IY WHITE PAPERS}

1. What is an oceanic ecosystem?

This question may seem naive because thousands of scientific articles have been written about ocean ecosystems, and the concept of Ecosystem-Based Management (EBM) of ocean resources is now widely accepted. However, Census' gap analysis (Fig. 1) of what we don't know about biodiversity in the ocean makes it clear that while some regions are well covered, others are not. The virtual absence of species records in the mid-waters between $1000 \mathrm{~m}$ depth and the benthos, means we really cannot claim to know the ecosystem of the largest volume of living space on the planet. Add to this the facts that new technologies are showing 100 times the diversity in microbial communities everywhere as anyone ever suggested before [23] and that the underestimation of the diversity of even something as common as marine snails is at least 10fold [24], and we see the gaps widen. Beyond that, even large, well know things like mammals, birds, reptiles and fishes have amazed us with their mobility, with tagged individuals occupying whole ocean basins and even multiple basins [1, 3, 4, 9 and 11]. This doesn't mean that we cannot talk meaningfully about regional shelf ecosystems encompassed by the Large Marine Ecosystem (LME) program [25], but it certainly makes it more complicated and requires that we keep both our minds and our ecosystems open. These mobile predators transfer energy between the known and the unknown habitats in complex four-dimensional matrices that will change with changing climate [26].

\section{How will global warming affect them?}

Continuous Plankton Recorder (CPR) data identified the northward translocation of warm water plankton communities in the North Atlantic more than a decade ago [27], and recent studies [28] suggest impacts of this on little auk chick survival in Svalbard where energy rich Arctic copepod species are being replaced by scrawny Boreal ones. Clearly, species composition matters. 

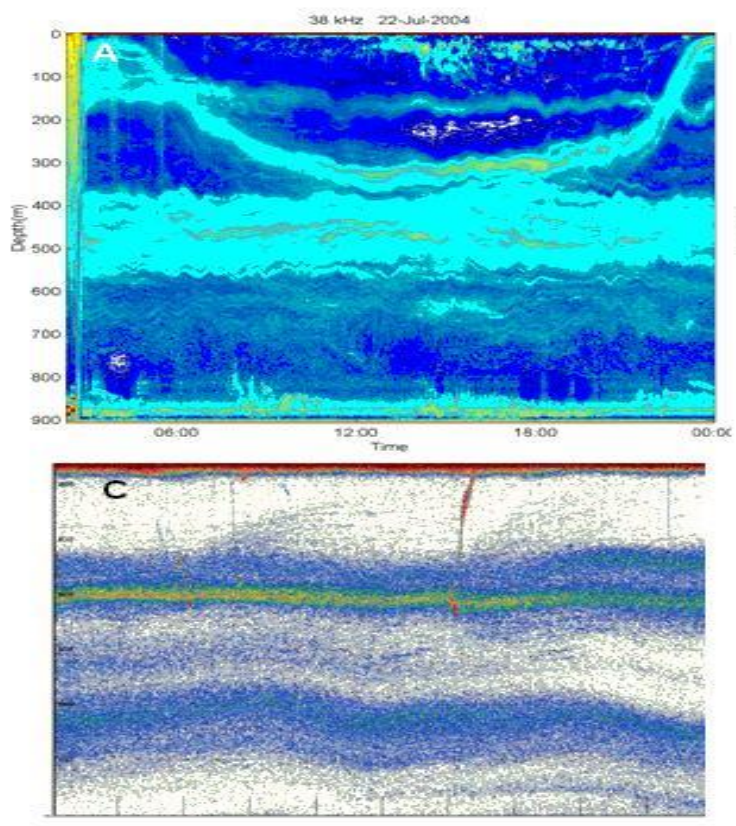
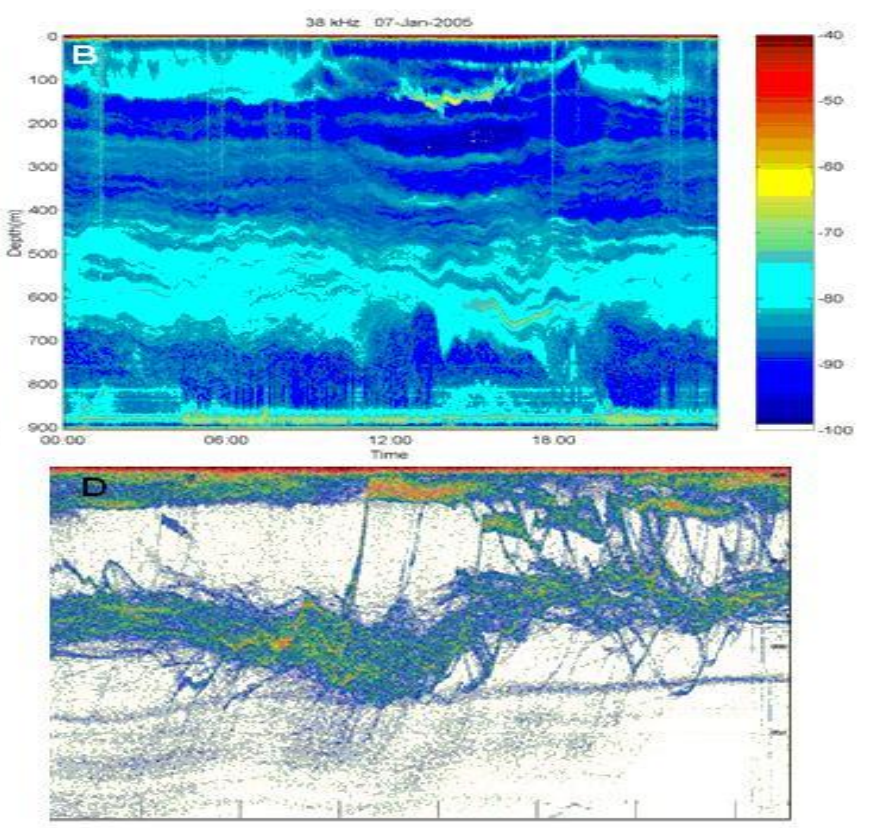

Figure 2. Upward-looking Simrad echosounder in the Charlie-Gibbs Fracture Zone on the Mid-Atlantic Ridge. (A) and $(B)$ : Dramatic reduction in diurnal plankton migration in winter $(B)$ versus summer $(A,(C)$ : $100 m$ whale dives to feed, likely on squid, above an internal wave moving the whole plankton community. (D): Fish school breaking up at $50 m$ and reforming near surface. Time bars $(C, D) 15$ min., Data from Census MAR-ECO (Marine Ecology Station) project [29 and 30].

These species are among the billion $\left(10^{9}\right)$ tons of biomass that migrate vertically, daily in complex seasonally and temperature-adjusted patterns throughout the oceans as illustrated in Fig. 2. Predicting the combined effects of the interactions of species at five trophic levels, changing patterns and interacting in rapidly shifting vertical and horizontal planes would challenge several supercomputers, if we had the data to enter the initial conditions. We do not. Is this question in the realm of the unknowable? In part the answer is yes, but there are suggestions below for steps to move forward with a progression of approximations.

\section{Will biodiversity decline? Will production decline?}

Again, these are incredibly important but complex questions, and despite the consensus that they are linked, the causal links and specific mechanisms are unclear, including the direction of change. Part of the complexity relates to time course and part to geography. It may actually be easier to predict answers to these questions a hundred years out when the situation is hopefully stabilizing than ten years out when everything is still changing rapidly. As scientists we tend to think the answers in global terms, but most people are likely thinking of answers in terms of their bay, their state or their nation.
The first guess would be that, overall, biodiversity will decline in the long term. We cannot predict the scale yet, but a major extinction event on the scale of those in the fossil record [31] cannot be ruled out. While many warm-water species can shift pole-ward, it is not clear where cold water species can go [26 and 32]. Deeper is a possibility for some, but not for those that also need light. A huge factor will be the impact of acidification on the coral reefs [33, 34, 35, 36, 37, 38, 39 and 40], which, like rain forests on land contain at least one third of the total diversity. We know that the synergistic effects of rising temperature and carbon dioxide levels will destroy many coral reefs globally, and there is no possibility that all of this biodiversity is duplicated or can be transferred naturally to other sites. Alex Rogers [14] recently proposed at the Copenhagen climate change meeting to stockpile frozen reef specimens and/or their DNA and relocate or restore these ecosystems later, but it is still too early to assume that this could be entirely successful. What is clear is that locally some mid-latitude regions will have increased biodiversity as tropical species invade while traditional species hang on.

The second guess would be that primary productivity might increase because of carbon dioxide available for photosynthesis, although the increased temperature over increased areas may have the opposite effect, decreasing 
productivity because of lowered solubility [33, 34, 35, 36, 37, 38, 39 and 40]. Changes in the vertical mixing required to cycle many essential nutrients might make things worse. There is accumulating evidence for decreasing vertical mixing in the oceans, and it is clear from past episodes that stable, layered oceans are much less productive than mixed ones [31]. It remains hard to predict where these changes are going. It seems fairly clear that secondary productivity will decline at the highest trophic levels, i.e. the things we most like to eat, because increasing temperatures will increase energy consumption and biomass at this level depends on a long chain of events in time and space that allow little fish to grow into big fish by being in the right place at the right time. This could be thought of as an extension of the Cushing match-mismatch hypothesis [41]. Changes in energy transfer through multiple trophic levels will be altered in both timing and location and these errors will accumulate at the highest trophic level. Some intermediate trophic levels will likely increase production because they don't get eaten. At the moment jellyfish and cephalopods seem to be doing well, but that could change. Perhaps we need to develop recipe books for new species as we fish down the food web [42]?
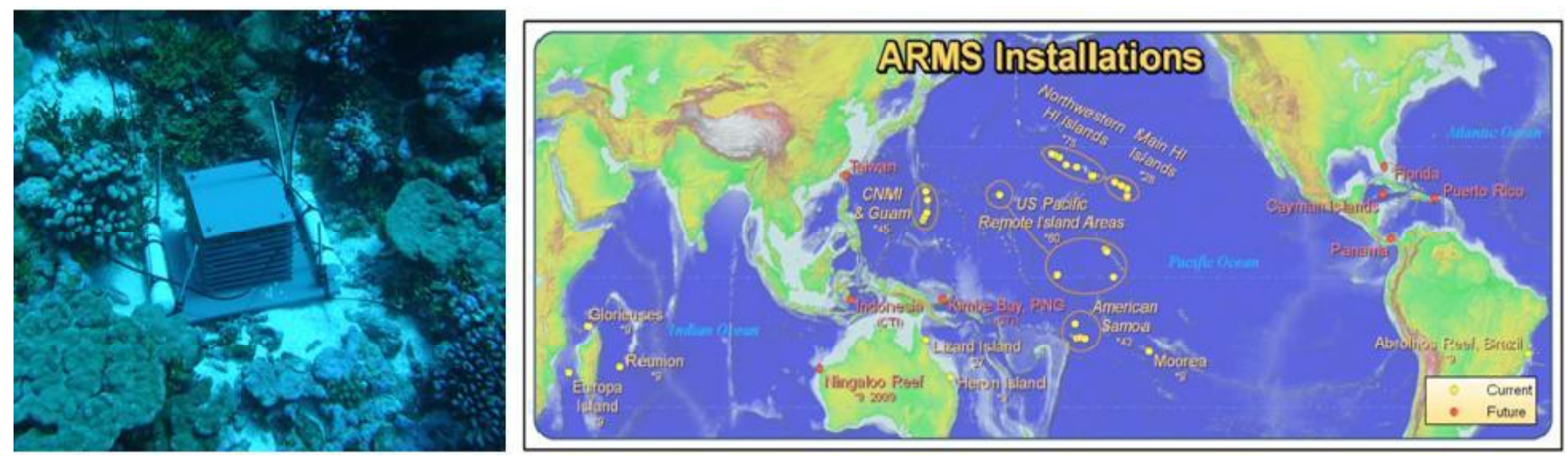

Figure 3. Autonomous Reef Monitoring System (ARMS), being deployed in most coral seas, provide a common basis for comparing biodiversity and biodiversity changes among regions. Easily adapted to rapid molecular approaches like barcoding.

\section{How much detail is needed to monitor biodiversity?}

Ocean biodiversity involves over a quarter-million known eukaryote species globally and tens of thousands at most individual sites. Add to these tens of thousands of microbial "operational taxonomic units" per litre of sea water [23] and the complexity becomes quite unmanageable. We must use simplifying automated approaches and likely identify "sentinel" species or taxa that are representative of the full biodiversity. Census has not yet done this in a comprehensive way, but several projects have taken great strides for particular habitats. In addition to the pyrosequencing approach already mentioned for microbes in water samples, the Zooplankton project is well advanced in creating DNA chips that will recognize all 10,000 or so holoplankter species collected in plankton nets and continuous plankton recorders globally from their DNA barcodes. The coral reef project has deployed Autonomous Reef Monitoring Structures (ARMS, Fig. 3) in most of the world's coral seas and is developing DNA barcode catalogs for all of the juvenile species that settle on these structures, which should result in similar DNA chips for various reefs. It requires a major construction project to carve out cubic meters of the hard reef material in which the tens of thousands of adult species hide [24], but recolonization of reefs occurs largely from temporarily planktonic larvae and juvenile forms that settle on ARMS. A year's worth of species can be scrapped off settlement plates and analysed rapidly for DNA without involving months of taxonomist time looking down microscopes, as current efforts establish the links between traditional morphometric descriptions and DNA barcodes and record them in online databases. The current state of the effort to barcode all marine species is shown in Fig. 4.

5. Can ecosystem-based management differentiate climate effects from fishing effects?

After a number of high-profile failures to manage a range of marine living resources [43], most nations globally have recognized [44] that there are strong interactions among species and strong influences of physical and chemical parameters on the way ecosystems function. Most nations are in the process of adopting and testing either "ecosystem-based management" (EBM) or "ecosystem approaches to management" (EAM) [45] now. 


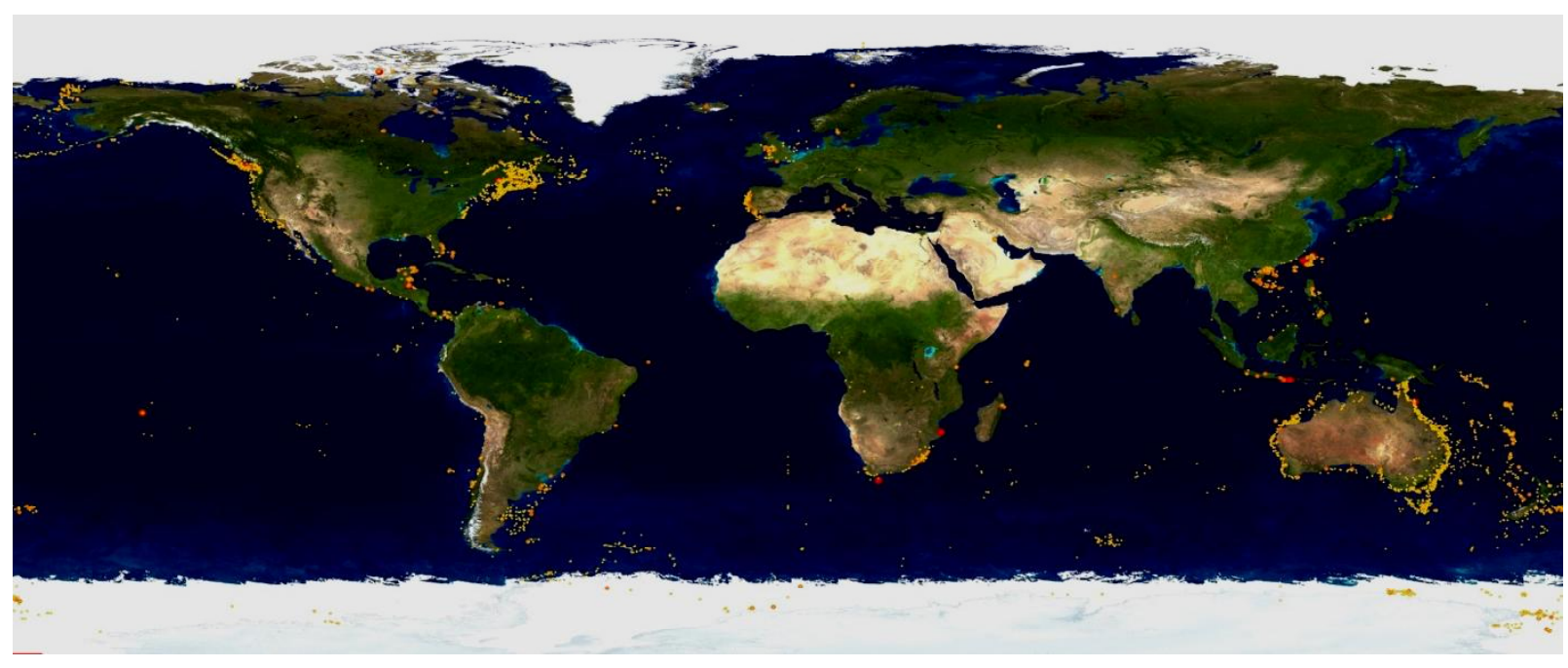

Figure 4. Current global marine coverage from the Barcode of Life project. Sites with 1-5 specimens, Yellow; 5-50, Orange; >50, Red.

These terms are largely interchangeable, but there really is not a fully developed protocol for the process anywhere, although the often quoted comment that "nobody knows what it means" is an overstatement. Everyone understands that there are major challenges in discovering and accounting for the many interactions that are only now emerging, but progress is being made and increasingly sophisticated models are being tested [46]. Traditional single species management models have been used for decades, but they still yield surprises when pushed beyond their limits.

The hardest part of question five is that most ocean ecosystems are now recognized as being out of balance in some way - too few top-down predators due to historical removals, too much bottom-up nutrient input from anthropogenic coastal sources, etc. [47, 48 and 49]. Add to this the fact that changes in climate are rapidly being superimposed in the systems and you have a severe challenge for modeling, including non-linear effects and scale-up challenges. Even if we were able to monitor every physical, chemical and biological change in some system, how long would we have to continue monitoring to clarify whether a particular effect was being driven by rising temperature or was simply part of the recovery from an imbalanced starting point in the traditional system?

\section{BUILDING ON SUCCESS}

Based on a decade of observation and testing of technologies in preparation for the reports at the 4 October 2010 Symposium in London, the Census has recommendations about the best ways to resolve the answers to the five questions above. These cannot all be detailed in this report, but we will try to provide a concise summary of what has been learned and what we think may be feasible, both technically and economically, to integrate biodiversity into the ocean observing system. Having the OBIS system available in IODE to record and display biodiversity data is an important step forward [50]. Although earlier we used OBIS to illustrate what we don't know about midwaters, it also records that there are some aspects of ocean biodiversity that we know reasonably well. Fig. 1 displays the assembled 22 million records in OBIS as biodiversity indices in one degree squares on a global scale in a Google Earth context. Panel A focuses of the best known North Atlantic and Panel B contrasts the least known South Pacific.

Figure 5 is the result of a request by the Tonga Minister of Fisheries at the FAO Committee on Fisheries meeting in 2008 for a map of what OBIS knows about diversity in his EEZ (Exclusive Economic Zone). This may not look too impressive to scientists, but such maps and the accompanying species lists are, for many countries, their best source of the information to catalog marine biodiversity as required by CBD. OBIS is now preparing a button on the website that can be pushed to automatically download such maps and lists to serve IOC member states.

It is worth pointing out that Census has never sent a project to Tonga to gather such information; it is simply the product of consolidating and searching over 700 databases from museums and agencies around the world that are learning the value of sharing data. The challenges of maintaining and updating such lists in the face of climate change are discussed in a section below. 


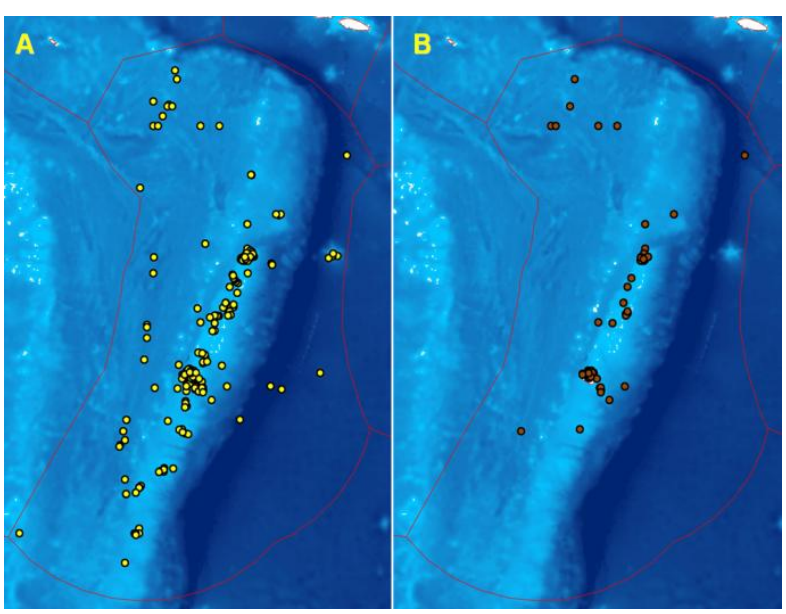

Figure 5. What OBIS knew about biodiversity in the Tonga EEZ during the FAO Committee on Fisheries meeting in 2008. (A) 786 fish species records, (B) 276 non-fish species records.

\section{OBSERVING THE MID-WATERS IN THE MID-OCEAN}

The discussion of Question 5 above raises a major problem for such an integrated system. The vast majority of ocean observing capabilities, except for satellite-based systems, are coastal and associated with various nations' EEZs. These relatively near shore observations are exactly the ones most likely to be heavily influenced by anthropogenic activities and, therefore, the ones where it is most difficult to unravel the historical human influences on ecosystems from the coming climate influences. We argue then that all of the other questions become easier to answer if we explore systematic ways to document and understand the complexity of relatively isolated offshore habitats, and then move this understanding back into the disturbed regions.

Fortunately, we have learned from some of our charismatic megafauna how to find the crucial oceanic "hotspot" ecosystems. The megafauna can search whole ocean basins for the food or other conditions they require in a matter of weeks [51], so they essentially answer Question 1, for us. An oceanic ecosystem is the accumulation of everything they visit. They also answer Question 2. These animals migrate to find the conditions they need. The locations of these conditions vary with climate annually anyway, so the longer term effects of global warming will be reflected in cumulative changes in migration patterns, which have already been followed routinely with high precision in meso-scale physical features using satellite approaches (Fig. 6) [3, 4 and 26]. In other words, many of the ocean's large predators are valuable as sensitive indicators of changing conditions in the physical oceans as well as the lower trophic levels, and a detailed understanding of their behavior will pay dividends.

Unfortunately, while the satellite approach lets us track megafauna and may be extended to the second trophic level by technologies like Fully Integrated Tagging [9], it doesn't get us all the way to bacteria, which are important both in terms of biomass and function, and feed into the dynamic vertical mixing caused by plankton migrations. Satellites can tell us a lot about phytoplankton and primary productivity, but not the full story [12]. Clearly the local ecosystems don't disappear when the megafauna move on, so there should be equipment left behind to find out what happens in such locations over time. MAR-ECO (Patterns and Processes of the Ecosystems of the Northern Mid-Atlantic) has, in fact, left upward-looking Simrad echosounders in place that record incredible details in a thousand meter water column (Fig. 2).

It would also be valuable to identify crucial ecosystem components in areas that can be continuously monitored. Many of these have been identified by the OceanSITES (OCEAN Sustained Interdisciplinary Time series Environment observation System) program [13], who would be prime potential partners. One of the most advanced observing systems on the planet is the Monterey Accelerated Research System cable in Monterey, CA, which, in fact, already has an upwardlooking Simrad echosounder connected to the cable and returning complex data in real-time (Fig. 7, www.acoustics.washington.edu/DEIMOS). This is a high-production, nearshore site, visited by a host of megafauna, so it might be a good place to transition.

Since 2008 Census has been collaborating with the International Union for Conservation of Nature; World Conservation Union (IUCN) in the Global Ocean Biodiversity Initiative, an international partnership advancing the scientific basis for conserving biological diversity in the deep seas and open oceans. It aims to help countries, as well as regional and global organizations, to use and develop data, tools, and methods to identify ecologically and biologically significant areas (EBSAs) with an initial focus on the high seas and deep seabed beyond national jurisdiction [52]. The work under this initiative ultimately aims to help countries meet the goals adopted under the Convention on Biological Diversity (CBD) and at the 2002 World Summit on Sustainable Development. These global goals relate to reducing the rate of biodiversity loss, applying ecosystem approaches, and establishing representative marine protected area networks by 2012 . 


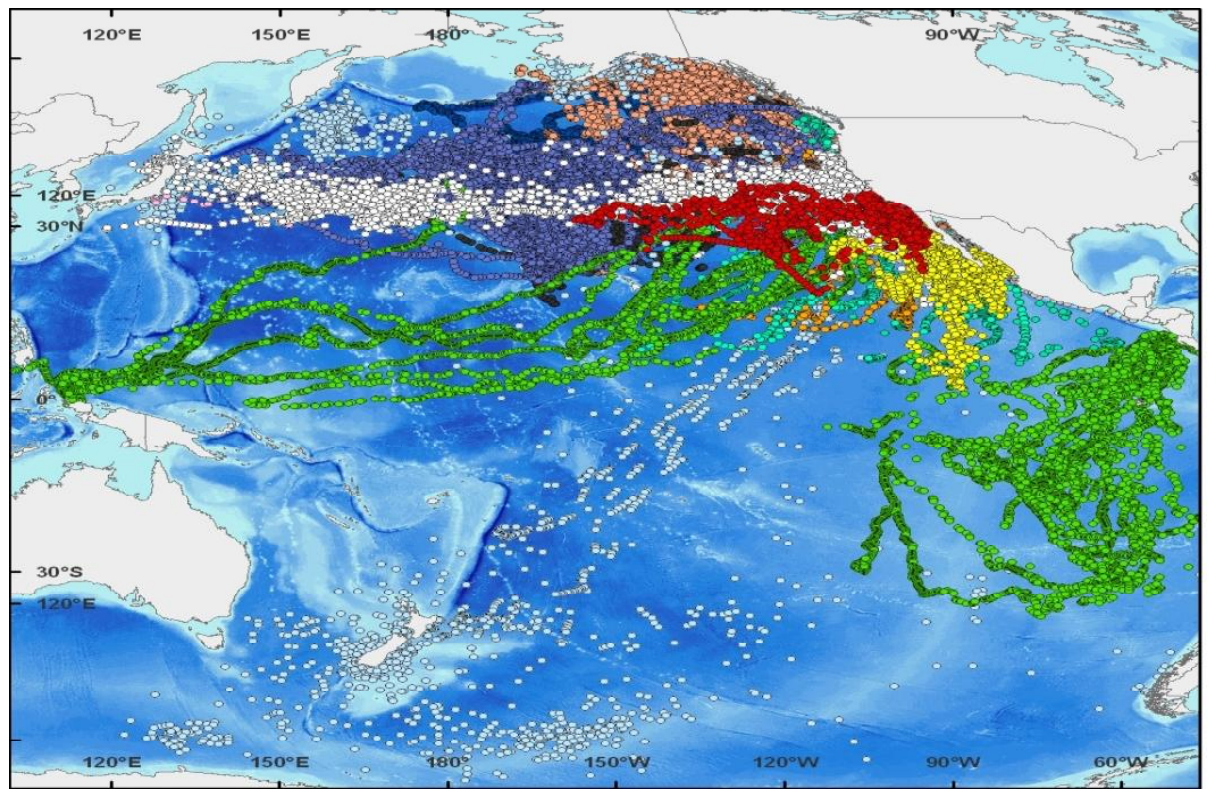

\author{
Black-footed Albatross \\ Blue Whale \\ California Sea Lion \\ Humpback Whale \\ Laysan Albatross \\ Northern Elephant Seal \\ Sooty Shearwater \\ Albacore \\ Blue Shark \\ Humboldt Squid \\ Leatherback Turtle \\ Loggerhead Turtle \\ Mako Shark \\ Mola \\ Pacific Bluefin \\ Salmon Shark \\ Thresher Shark \\ White Shark \\ Yellowfin Tuna
}

Figure 6. Tracks of 19 species of marine vertebrates tracked as part of the TOPP program. The tracks show areas of overlap and common habitat utilization. These data are being examined with respect to the underlying oceanographic features that may be responsible for these patterns (see www.topp.org).
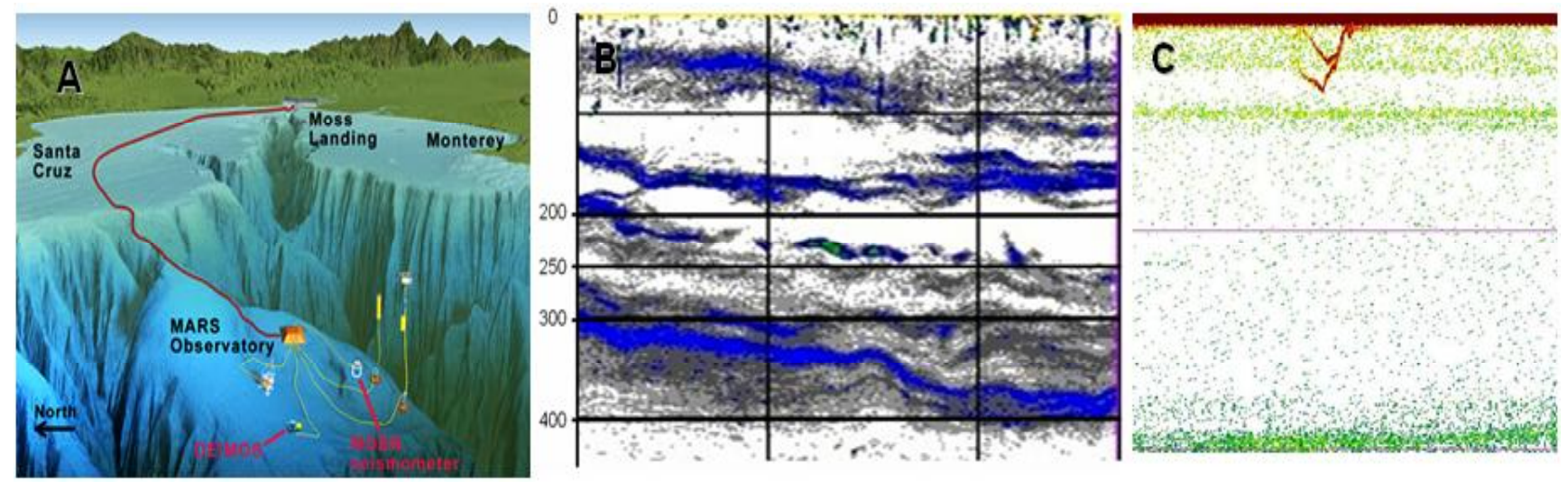

Figure 7. (A) DEIMOS (Deepwater Echo Integrating Marine Observatory System), the upward looking sonar on the MARS observatory in Monterey Bay, California. (B) Classes of organisms in the various layers observed during an (Remotely operated vehicle) ROV dive 6 May 2009. 200-250m - chaetognaths, euphausiids, polychaetes, isopods, and a few myctophids, 300-400m - chaetognaths, tunicates, jellyfish, siphonophores, polychaetes, salps, and a few myctophids and squid. (C) Two animals diving to about 30m in the view of DEIMOS - probably seals.

In 2008 the CBD Parties adopted a set of seven scientific criteria to identify EBSAs in the global marine realm: (1) Uniqueness or rarity, (2) Special importance for life-history stages of species, (3) Importance for threatened, endangered or declining species and/or habitats, (4) Vulnerability, fragility, sensitivity, or slow recovery (5) Biological productivity, (6) Biological diversity, (7) Naturalness. It turned out that many of the
Census projects were focused of areas that fit naturally with these criteria such as Seamounts and Vents and Seeps - even the Top Predators help define these areas so this collaboration has been very fruitful. As the areas are designated and protected they will also become obvious foci for permanent observatories or at least regular monitoring to maintain Naturalness. 


\section{RECONSTRUCTING BIODIVERSITY PATTERNS \\ NEARSHORE}

Conceptually at least, as observations of isolated open ocean ecosystems build our confidence that we can model and understand "end-to-end ecosystems" and tease out the interacting affects of ecosystem disturbance and global warming, we should be able to transfer this knowledge back to the highly disturbed, but better observed and documented coastal zones. Census' Oceans Past project has shown that reasonably detailed observational records of higher trophic level biodiversity can be reconstructed from unlikely literature sources [53]. Such long time-series going back a thousand years before direct scientific observational data began being collected have allowed the Census Oceans Future project to project trends and conclude that even areas where biodiversity has been devastated over centuries show significant signs of recovery when protected for years to decades [54]. This perhaps suggests a new strategy for the ocean observing community, to add biodiversity time-series reconstruction to their mandate. Certainly the community recognizes the value of temperature and oxygen time-series, for example, for understanding current events, but may not be aware of this potential for biodiversity. Before the oceanographic community says, "Great, one more thing to pay for!" We should add an anonymous quote, "Historians work for even less than biologists."

In addition to the coral reef project mentioned earlier, Census has a Near Shore project that has already initiated a global time-series using low cost protocols for sampling seagrass and rocky shore habitats (Fig. 8).

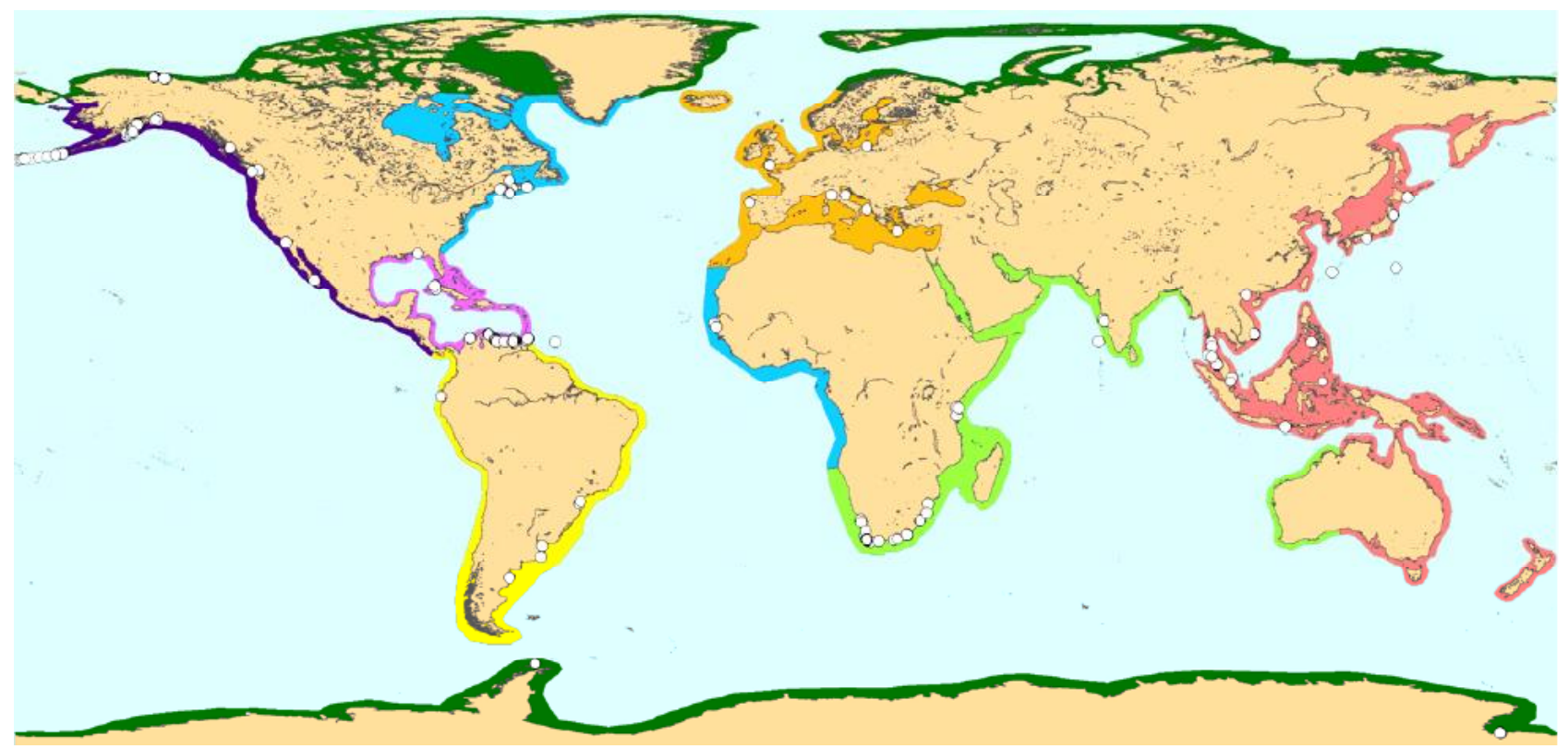

Figure 8. The current global coverage of sites where the NaGISA (Natural Geography in Shore Areas; Natural Geography in Near Shore Areas) Protocols [55] have been conducted. Some of these sites are committed to repeated sampling for up to 50 years

These have been adopted by local communities, citizen scientists, university and even high school classes, so they can be conducted by volunteers and create local interest, awareness and involvement [55]. The only hard part of this process is identifying the biodiversity collected, but like Reefs and Zooplankton this project is moving quickly toward DNA barcode approaches that can provide near real-time results about changing patterns and invasive species in the places people care about most. Barcoding will be a powerful new tool for linking local physical and chemical observations to changing biodiversity.In a similar vein, the discussants at the Census Biodiversity Forum recognized unanimously that the CPR data provided by the Sir
Alister Hardy Foundation for Ocean Science (SAHFOS) for more than 60 year is likely the single most important biodiversity time series available and it is crucial to maintain as an observational tool [10]. It, too, is data collected largely by volunteers, in this case commercial vessels, and is a great bargain. SAHFOS is working rapidly to replace direct morphological taxonomy with rapid molecular techniques to accelerate data accession processes and reduce costs. The Forum recommended that the development of this technology and new, perhaps near real-time, analytical tools be developed for updated CPR platforms that could include physical and chemical sensors as well as biological ones, for greater data integration. The observing community was also 
urged to work to expand CPR routes to more places, particularly in developing countries, which will be heavily impacted by global warming and have the greatest need to expand the information base about their biodiversity and how it is changing.

\section{MONITORING CHANGING MOBILE SPECIES PATTERNS}

The Ocean Tracking Network (OTN) [9], a GOOS pilot project, is another valuable tool for reconstructing largescale relationships among commercial and conservation species in the coastal regions. It incorporates elements of the Census Tracking of Pacific Predators (TOPP) [4] and Pacific Ocean Shelf Tracking (POST) projects to provide long-term data on animals moving between acoustic receiver curtains over large distances, but is primarily built around a global collaboration of smallscale tagging and tracking projects that share data to learn surprising facts about where animals go when they leave "home". The discovery of endangered green sturgeon from California rivers in British Columbia and Alaska by the Census POST project [56] is a now classic example, but similar surprises are now turning up in the Atlantic OTN as the system expands. Fig. 9 illustrates the principles of OTN well. By sharing data on Atlantic salmon smolts tagged by the National Oceanic and Atmospheric Administration (NOAA) and the Atlantic Salmon Federation (ASF) in local studies of migrations from southern rivers in 2008 and 2009, fish have already been detected crossing the OTN Halifax Line and by Fisheries and Oceans Canada equipment arrays in Newfoundland and Labrador. The total distance traveled by these tiny fish already rivals that of the giant sturgeon. Because much of the equipment currently in place has to be recovered to collect data, we expect many more detections as data are assembled.

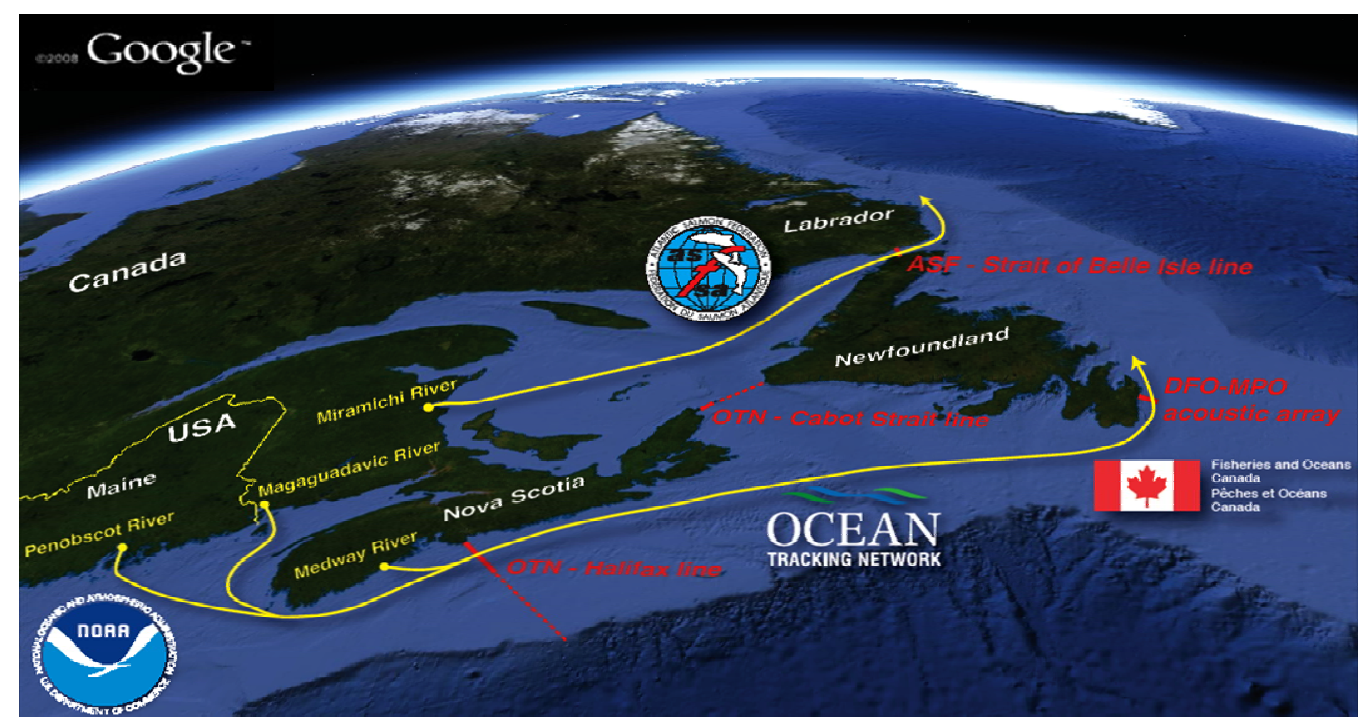

Figure 9. International cooperative tracking of endangered Atlantic salmon using Ocean Tracking Network data management system (www.oceantrack.org), creates tracks like these, involving NOAA (National Oceanic and Atmospheric Administration), Fisheries and Oceans Canada and the Atlantic Salmon Federation. Are they headed to Greenland next?

One of the strengths of the OTN is the addition of permanent lines like the one in Halifax that can download data via acoustic modems without retrieval, which moves OTN toward a routine observing system within GOOS. OTN is already testing real-time communications between its receivers and the cabled VENUS system in Victoria, BC. Fig. 10 illustrates further recent progress as collaborators in Spain and Morocco have completed high resolution swath mapping of the area in the Strait of Gibraltar where a permanent OTN line will be added in 2010. We should note that these lines collect unique synchronous timeseries data from physical and chemical sensors colocated with the animal detecting receivers. This will, of course, be shared with the oceanographic community. Understanding flow fields in the Strait will be key to understanding behaviors of both the local and longrange species that cross this line between LMEs.

An observing system that that monitors ocean species on a range of temporal and spatial scales should yield benefits to fisheries agencies that need to better understand links between climate and the survival of marine species, and some management applications have already arisen. The TOPP approach helped improve management of Atlantic bluefin tuna by showing unambiguously that eastern and western stocks were linked, and TOPP tracking data were overlaid on 
oceanographic patterns to develop predictive mapping tools that help the Navy avoid endangered whales and central Pacific commercial fishermen avoid migrating sea turtles. Data from the POST project has been used to designate critical habitat for green sturgeon and is being used to test old theories about early ocean survival in juvenile salmon. POST has begun discussions with US and Canadian fisheries agencies about integrating data from acoustic arrays into operational fisheries run forecasting on the Pacific coast of North America.

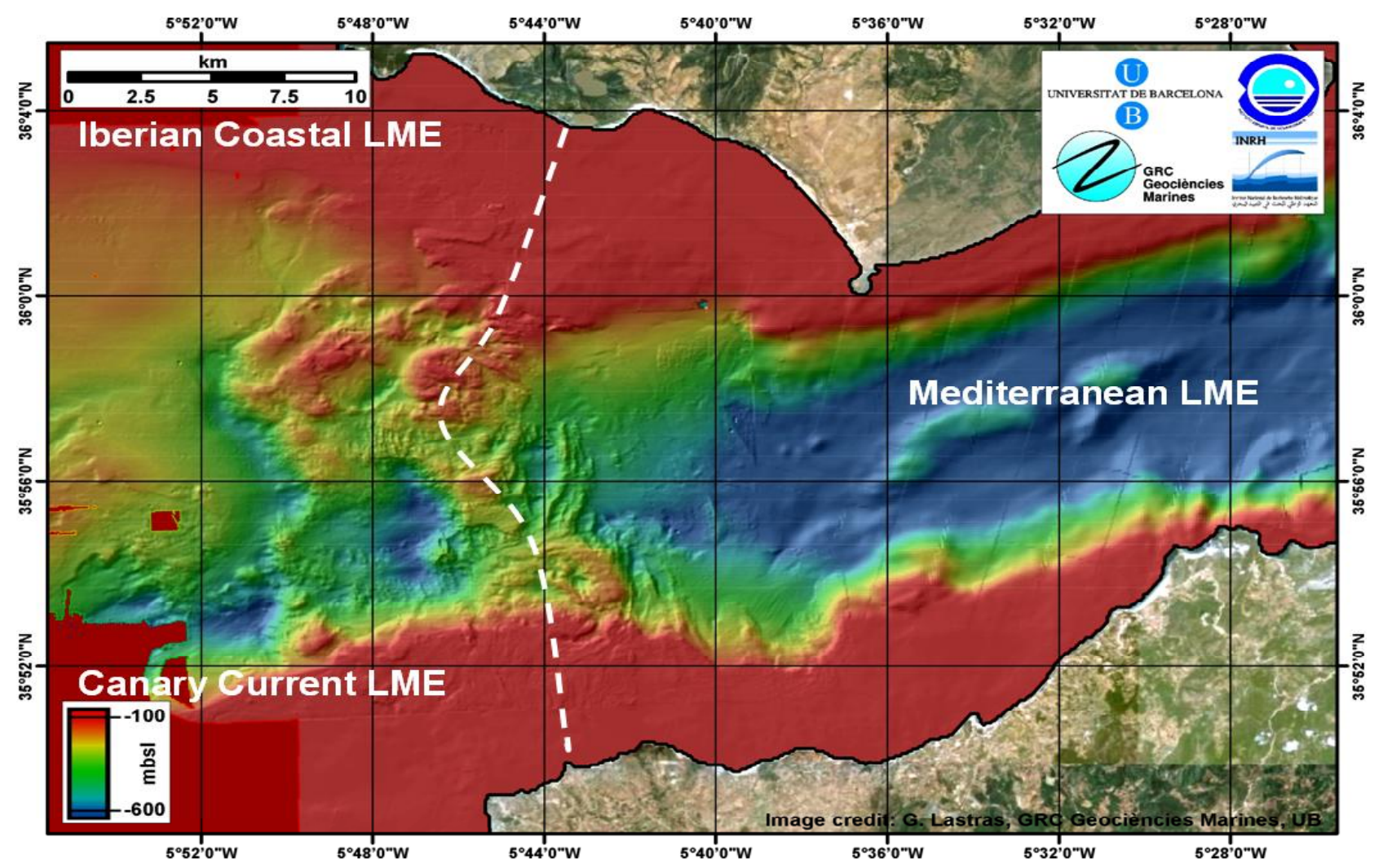

Figure 10. New high-resolution bathymetry from Spain to Moroccan guides construction of the OTN Gibraltar Line by placing equipment on a longer but shallower line to improve tracking sensitivity here at the crucial interface of the Mediterranean, Iberian Coastal and Canary Current LMEs. (Courtesy of Universitat de Barcelona and Instituto Español de Oceanografía)

\section{ANIMAL OCEANOGRAPHERS}

Another crossover area between traditional observing and biological observing that was a focus of many CWPs [1, 3, 4 and 11] was the use of animals as platforms for collecting near real-time physical and chemical data. Although the paramount reason for tagging animals is to understand where they go and identify their critical habitats [57], as discussed earlier, animals are returning high quality oceanographic data at higher rates and from places like frontal zones and under ice that are inaccessible to the highly successful Argo (Global array of free-drifting profiling floats) Float program. Data from animal platforms is rapidly making its way into oceanographic data centers and models and recent data is timely and indistinguishable in quality from Argo (Array for Real-time Geostrophic
Oceanography) data [58]. Outfitting animals with equivalent sensor arrays and collecting their data is no more costly than Argo Floats, and most animals require zero ship time to launch! There is no suggestion that animal oceanographers can replace Argo Floats, permanent moorings, drifters or traditional oceanographic cruises, but more careful coordination between the biological and oceanographic communities could produce better coverage and reduce costs for ocean observing.

\section{CENSUS 2010}

Canadian Geographic [59] recently referred to Census as The Transparent Oceans Project, which we think is apt because Census has done much to make the oceans less dark and mysterious. As pointed out above, this 
doesn't mean that there is nothing left to learn, but that technologies for observing all parts of the ocean now exist and need to be applied systematically to monitor the many changes that will occur over the coming decades. A recent prelude [19] to the Census 2010 reports puts this transparency in spectacular view with over 250 images. The goal of this plenary presentation and paper is to make it clear that the Census community does not view 2010 as an end, but a beginning. This large global team of marine scientists keenly recognizes that the true value of a census is not the baseline it lays down, but the ability to measure changes against that baseline over time.

\section{CENSUS 2020}

As outlined above Census 2010 has dramatically improved our view of the open and deep ocean and provided valuable evidence that is being used, for example, to justify and designate ecologically or biologically significant areas (EBSAs) [17, 18 and 52] and defining habitats [60]. Census 2010 has trained a new generation of researchers and developed new social networks that have increased our intellectual capacity; it has developed new technologies, analytical approaches, data assimilation, and visualization techniques. The Census Science Council 2020 is developing a follow on effort Census of Marine Life 2020: Life in a Changing Ocean that will integrate the various successful approaches tested during Census 2010 to maintain this momentum and dynamically expand it in areas where animals congregate. The concept of an "Ecoscope" is being developed as a way of looking at the nested scales of the ecosystem in a dynamic way. The Ecoscope concept is essentially an integrated end-to-end view of a particular marine environment where measurements of the movement patterns of top predators are coupled with the abundance of zooplankton and the associated ocean physics. The plan is to focus our Ecoscope on a few key regions where existing infrastructure is in place or where important critical habitats have been identified. The current projects could suggest where to point the Ecoscope, perhaps an anoxic zone driven by microbes, the largest deep sea vent, or a recently discovered coral seamount - in the Arctic! Megafauna could also define their needs at the largest scale.

It is unclear how many vessels or samplers it would take to do the full spectrum of life, Census' Mid-Ocean Ridges project has shown us that an advanced research vessel like the G.O Sars, supported by an independent sampling vessel can define the ecosystem in a column of water from top to bottom and potentially from bacteria to whales [20]. Using advanced acoustic and video imaging systems on ROV and AUV samplers, combined with onboard DNA sequencing technology, perhaps a single vessel could define a piece of an ecosystem in near real-time and then move on to define the next piece of the ecosystem the chosen by mobile megafauna. This may not be the best approach to discover important new benthic sites, but really the only way to learn if there are strong interactions from the benthos through the entire water column is to try the Ecoscope. As indicated, the results from Census 2010 have lacked this level of site integration and there are really no good examples of this type of study to draw on.

In contrast there is a wealth of information on the coastal LMEs [25] and Science Council is working to integrate its plans with these programs and with those of the GOOS Coastal Module [8]. As an example, OTN and its partners [9] plan to install benthic lines of acoustic receivers and physical samplers in $60 \%$ of the 66 currently identified LMEs. A recent comprehensive report on LMEs [25] includes a review of the trends in fisheries biomass in LMEs experiencing varying levels of warming [61] that support earlier conclusions [62,63] that fish stocks are moving toward the poles in midlatitudes. However, variations in management regimes mask these trends in many tropical areas [64]. One of the advantages of the OTN approaches is that it provides indicators of fish movements in weeks rather than the years often required to gather and integrate catch and even survey data on where fish are.

Although OTN itself is focused on mobile species and the physical environment they experience, Census 2020, is working to integrate these rapidly responding species with the broader associated changes in biodiversity. The current technology for OTN lines requires that vessels move over the line to recover the data with acoustic modems on a regular schedule. Such vessels offer platforms for regular sampling within LMEs out to the continental slopes. In Canada where the largest concentration of OTN lines are located, plans are underway to add standardized sampling of other habitats where vessels are traversing the lines in cooperation with other biodiversity monitoring programs [65]. Thus, there could be routine biodiversity monitoring in LMEs, starting with routine Near Shore protocols, sampling for Microbes, Zooplankton and benthos along the line and even additional sampling on Continental Margins and their Seeps and Vents. All of the coastal projects could have a continuous source of new material to study. As these protocols are tested in Canada, they can be transferred to other OTN lines around the world.

We recognize that long-term observing in these vast ocean regions is a demanding and expensive proposition. Census 2010 Ocean Realms projects have shown the community tools to make continuing observations of biodiversity affordable. Planning for Census 2020 is providing approaches that will allow the move toward biodiversity observing to be staged and orderly, moving from what we can do immediately to what we must do before crises grow. There is still much to discover, but 
in many parts of the ocean ecosystem baselines have been created against which future changes can be compared. The Oceans Past and Oceans Future projects have shown that this ecosystem has resilience, but monitoring is essential to assess whether management tools are being used effectively.

\section{ACKNOWLEDGEMENTS}

We are extremely grateful for the many opportunities the ocean observing community made available to us at OceanObs'09 to present the case that biodiversity is not only important, but observable, and for the patience shown for the "new kids in town". We realize that funding for enduring activities is a tremendous challenge at the best of times, but we believe that the value society places on biodiversity and the recognition it brings to science will help build stable funding for the broader observing community as we go forward.

\section{REFERENCES}

1. Boehme, L. \& Co-Authors (2010). "Biologging in the Global Ocean Observing System" in these proceedings (Vol. 2), doi:10.5270/OceanObs09.cwp.06.

2. Brainard, R. \& Co-Authors (2010). "An International Network of Coral Reef Ecosystem Observing Systems (I-CREOS)" in these proceedings (Vol. 2), doi:10.5270/OceanObs09.cwp.09.

3. Charrassin, J. \& Co-Authors (2010). "New Insights into Southern Ocean Physical and Biological Processes Revealed by Instrumented Elephant Seals" in these proceedings (Vol. 2), doi:10.5270/OceanObs09.cwp.15.

4. Costa, D., Block, B., Bograd, S., Fedak, M. and Gunn, J., (2010). "TOPP as a Marine Life Observatory: Using Electronic Tags to Monitor the Movements, Behaviour and Habitats of Marine Vertebrates" in these proceedings (Vol. 2), doi:10.5270/OceanObs09.cwp.19.

5. Feely, R. \& Co-Authors (2010). "An International Observational Network for Ocean Acidification" in these proceedings (Vol. 2), doi:10.5270/OceanObs09.cwp.29.

6. Handegard, N. \& Co-Authors (2010). "Toward a Global Ocean Ecosystem Mid-Trophic Automatic Acoustic Sampler (MAAS)" in these proceedings (Vol. 2), doi:10.5270/OceanObs09.cwp.40.

7. Koslow, J., Goericke, R., McClatchie, S., Vetter, R. and Rogers-Bennett, L., (2010). "The California Cooperative Oceanic Fisheries Investigations (CalCOFI): the Continuing Evolution and Contributions of a 60-Year Ocean Observation Program" in these proceedings (Vol. 2), doi:10.5270/OceanObs09.cwp.49.

8 Malone, T. \& Co-Authors (2010). "Building a Global System of Systems for the Coastal Ocean: A Strategic Action Plan for Implementing the Coastal Module of GOOS" in these proceedings (Vol. 2), doi:10.5270/OceanObs09.cwp.59.
9. O'Dor, R. \& Co-Authors (2010). "The Ocean Tracking Network" in these proceedings (Vol. 2), doi:10.5270/OceanObs09.cwp.66.

10. Reid, P. \& Co-Authors (2010). "A Global Continuous Plankton Recorder Programme" in these proceedings (Vol. 2), doi:10.5270/OceanObs09.cwp.73.

11 Rintoul, S. \& Co-Authors (2010). "Southern Ocean Observing System (SOOS): Rationale and Strategy for Sustained Observations of the Southern Ocean" in these proceedings (Vol. 2), doi:10.5270/OceanObs09.cwp.74.

12. Sathyendranath, S. \& Co-Authors (2010). "ChloroGIN: Use of satellite and In Situ Data in Support of Ecosystem-Based Management of Marine Resources" in these proceedings (Vol. 2), doi:10.5270/OceanObs09.cwp.75.

13. Send, U. \& Co-Authors (2010). "Towards an Integrated Observing System: In Situ Observations" in these proceedings (Vol. 1), doi:10.5270/OceanObs09.pp.35.

14. Gunn, J., Rogers, A. and Urban, E., (2010). "Observation of Ocean Biology on a Global Scale: Implementing BioGOOS?" in these proceedings (Vol. 1), doi:10.5270/OceanObs09.pp.20

15. Vanden Berghe, E., Halpin, P., Lang da Silveira, F., Stocks, K. and Grassle, F., (2010). "Integrating Biological Data into Ocean Observing Systems: The Future Role of OBIS" in these proceedings (Vol. 2), doi:10.5270/OceanObs09.cwp.91.

16. National Research Council, Committee on Biological Diversity in Marine Systems (1995). Understanding Marine Biodiversity, National Academy Press, Washington, DC.

17. Ardron, J., Dunn, D., Corrigan, C., Gjerde, K., Halpin, P., Rice, J., Vanden Berghe, E. \& Vierros, M. (2009) Defining ecologically or biologically significant areas in the open oceans and deep seas: Analysis, tools, resources and illustrations. http://www.cbd.int/doc/meetings/mar/ewbcsima01/other/ewbcsima-01-multiorgs-en.pdf

18. UNEP/CBD/EW-BCS\&IMA/1/2 (2009). Report of the expert workshop on ecological criteria and biogeographic classification systems for marine areas in need of protection. 22 December http://www.cbd.int/doc/meetings/mar/ewbcsima01/official/ewbcsima-01-02-en.doc

19. Crist, D. Scowcroft, G. \& Harding, J. (2009). World Ocean Census: A Global Survey of Marine Life, Firefly Books, Richmond Hill, Canada, 256pp.

20. Bergstad, O.A., Falkenhaug, T., Astthorsson, O.S., Byrkjedal, I., Gebruk, A.V. Piatkowski, U., Priede, I.G., Santos, R.S., Vecchione, M., Lorance, P. \& Gordon, J.D.M. (2008). Towards improved understanding of the diversity and abundance patterns of the mid-ocean ridge macro- and mega-fauna. Deep-Sea Res. II 55, 1-5. (Introduction to a special volume)

21. Makris, N.C., Ratilal, P., Symonds, D.T., Jagannathan, S., Lee, S. \& Nero, R. (2006). Fish population and behavior 
revealed by instantaneous continental-shelf-scale imaging, Science 311, 660-663.

22. Webb, T.J., Vanden Berghe, E. and O'Dor, R.K. (submitted) Biodiversity's big wet secret: chronic under exploration of the deep pelagic ocean. PLoS One.

23. Sogin, M.L., Morrison, H.G., Huber, J.A., Welch, D.M., Huse, S.M., Neal, P.R., Arrieta, J.M. \& Herndl, G.J., (2006). Microbial diversity in the deep sea and the underexplored "rare biosphere", Proc. Nat. Acad. Sci. USA 103, 12115-12120.

24. Bouchet, P., Lozouet, P., Maestrati, P. \& Heros, V. (2002). Assessing the magnitude of species richness in tropical marine environments: exceptionally high numbers of molluscs at a New Caledonia site. Biol. J. Linn. Soc. 75, 421-436.

25. Sherman, K. and Hempel, G. (Eds) (2009). The UNEP Large Marine Ecosystem Report: A perspective on changing conditions in LMEs of the world's Regional Seas. UNEP Regional Seas Report and Studies No. 182. United Nations Environment Programme. Nairobi, Kenya. 852 pp.

26. Costa, D.P., Huckstadt, L., Crocker, D. E., McDonald, B., Goebel, M.E. \& Fedak, M.A. (in press) Approaches to Studying Climatic Change and its Role on the Habitat Selection of Antarctic Pinnipeds Integr. Comp. Biol. (2010) 50(6): 1018-1030 first published online June 3, 2010 doi:10.1093/icb/icq054 Integr. Com. Biol.

27. Beaugrand, G., Reid, P.C., Ibañez, F., Lindley, J.A. \& Edwards, M. (2002). Reorganization of North Atlantic marine copepod biodiversity and climate. Science 296, 1692-1694.

28. Stempniewicz, L., Bachowiak-Samoyk, K. \& Wesawski, J.M. (2007). Impact of climate change on zooplankton communities, seabird populations and arctic terrestrial ecosystem - a scenario. Deep-Sea Res. II 54, 2934-2945.

29. Doksæter, L., Godø, O.R., Olsen, E., Nøttestad, L. \& Patel, R. (2009). Using a bottom mounted Lander as a tool for observations and ecological study of cetaceans and their prey. ICES J. Mar. Sci. 66, 1029-1036.

30. Godø, O.R., Handegard N.O., Patel, R., Torkelsen, T. \& Totland, A. (submitted) Stationary acoustic systems for monitoring ecosystem dynamics. Limnol. Oceanog.

31. Ward, P.D. (2008). Precambrian strikes back. New Scientist 197 (2642), 40-43.

32. McClintock, J., Ducklow, H. \& Fraser, W. (2008). Ecological responses to climate change on the Antarctic Peninsula, American Scientist 96, 302-310.

33. Dybas, C.L. (2006). On a collision course: Ocean plankton and climate change. Bioscience 56, 642-646.

34. Hoegh-Guldberg, O, Mumby, P.J., Hooten, A.J., Steneck, R.S., Greenfield, P., Gomez, E., Harvell, C.D., Sale, P.F., Edwards, A.J., Caldeira, K., Knowlton, N., Eakin, C.M., Iglesias-Prieto, R., Muthiga, N., Bradbury, R.H., Dubi, A. \& Hatziolos, M.E. (2007). Coral reefs under rapid climate change and ocean acidification. Science 318 , $1737-1742$.
35. Stanley, G.D. (2007). Ocean acidification and scleractinian corals. Science 317, 1032-1032.

36. Hunt, B.P.V., Pakhomov, E.A., Hosie, G.W., Siegel, V., Ward, P. \& Bernard K. (2008). Pteropods in Southern Ocean ecosystems. Progress in Oceanography 78, 193221.

37. Iglesias-Rodriguez, M.D., Halloran, P.R., Rickaby, R.E.M., Hall, I.R., Colmenero-Hidalgo, E., Gittins, J.R., Green, D.R.H., Tyrrell, T., Gibbs, S.J., von Dassow, P., Rehm, E., Armbrust, E.V. \& Boessenkool, K.P. (2008). Phytoplankton calcification in a high-CO2 world. Science 320, 336-340.

38. McNeil, B.I. \& Matear, R.J. (2008). Southern Ocean acidification: A tipping point at 450-ppm atmospheric CO2. Proc. Nat. Acad. Sci. USA 105, 18860-18864.

39. Rosa, R. \& Seibel, B.A.. (2008). Synergistic effects of climate-related variables suggest future physiological impairment in a top oceanic predator. Proc. Nat. Acad. Sci. USA 105, 20776-20780.

40. Hofmann, M. \& Schellnhuber, H. J. (2009). Oceanic acidification affects marine carbon pump and triggers extended marine oxygen holes. Proc. Nat. Acad. Sci. USA 106, 3017-3022.

41. Cushing, D.H. (1990). Plankton production and year-class strength in fish populations: an update of the match/mismatch hypothesis. in Advances in Marine Biology (eds) JHS Blaxter and AJ Southward. Academic Press Limited, San Diego, CA. pp 250-313.

42. Pauly, D., Christensen, V., Dalsgaard, J., Froese, R. \& Torres Jr, F. (1998). Fishing down marine food webs. Science 279, $860-863$, doi:10.1126/science.279.5352.860.

43. Stokstad, E. (2009). Global Fisheries: Détente in the fisheries war. Science 324, 170-171.

44. Pikitch, E.K., Santora, C., Babcock, E.A., Bakun, A., Bonfil, R., Conover, D.O., Dayton, P., Doukakis, P. Fluharty, D., Heneman, B., Houde, E.D., Link, J., Livingston, P.A. Mangel, M., McAllister, M.K, Pope, J. \& Sainsbury, K.J. (2004). Ecosystem-based fishery management Science 305, 346-347. doi:10.1126/science. 1098222

45. Murawski, S.A., Steele, J.H., Taylor, P., Fogarty, M.J., Sissenwine, M. P., Ford, M. \& Suchman, C. (In press). Why compare marine ecosystems?, ICES J. Mar. Sci. 67, 000-000.

46. Moustahfid, H., Tyrrell, M.C. \& Link, J.S. (2009). Accounting explicitly for predation mortality in surplus production models: an application to longfin inshore squid. N. American J. Fisheries Management 29, 15551566.

47. Baum, J. K., Myers, R.A., Kehler, D.G., Worm, B., Harley, S.J. \& Doherty, P.A. (2009). Collapse and conservation of shark populations in the Northwest Atlantic. Science 299, 389-392. 
48. Myers, R.A. \& Worm, B. (2003). Rapid worldwide depletion of predatory fish communities. Nature 423, 280-283.

49. Worm, B., Lotze, H.K. \& Myers, R.A. (2003). Predator diversity hotspots in the blue ocean. Proc. Nat. Acad. Sci. USA 100, 9884-9888.

50. IOC (2010). OBIS (Ocean Biogeographic Information System) Strategy and Workplan Meeting, IOC Project Office for IODE, Oostende, Belgium, 18-20 November 2009 Workshop Report No. 226. http://www.iode.org/wr226.

51. O'Dor, R.K., Fennel, K \& Vanden Berghe, E. (2009). A One Ocean Model of Biodiversity. Deep Sea Res. II 56, 18161823.

52. IUCN (2010). Global Ocean Biodiversity Initiative: Working towards high seas conservation. http://www.gobi.org./ .

53. Lotze, H.K. (2007). Rise and fall of fishing and marine resource use in the Wadden Sea, southern North Sea. Fish. Res. 87 (2-3), 208-217 (Special volume).

54. Lotze, H.K., Lenihan, H.S., Bourque, B.J., Bradbury, R.H., Cooke, R.G., Kay, M.C., Kidwell, S.M., Kirby, M.X. Peterson, C.H. \& Jackson, J.B.C. (2006). Depletion, degradation, and recovery potential of estuaries and coastal seas. Science 312, 1806-1809.

55. Rigby, P.R., Iken, K. \& Shirayama, Y. (Eds.) (2007). Sampling Biodiversity in Coastal Communities: NaGISA Protocols for Seagrass and Macroalgal Habitats. Kyoto University Press; 145 pages; ISBN: 9784876987009.

56. Lindley, S.T., Moser, M.L., Erickson, D.L., Belchik, M., Welch, D.W., Rechisky, E.L., Kelly, J.T., Heublein, J. \& Klimley, A.P. (2008). Marine migration of North American green sturgeon. Trans. Am. Fish. Soc. 137, 182-194.

57. Rutz, C \& Hays, G.C. (2009). New frontiers in biologging science. Biol. Lett. 5(3), 28992. .doi:10.1098/rsbl.2009.0089.

58. Fedak, M., Personal communication.

59. DeMont, J. (2009). The Transparent Oceans Project. Canadian Geographic 129 (3), 44-53.

60. Costello, M.J. (2009). Distinguishing marine habitat classification concepts for ecological data management. Mar. Ecol. Prog. Ser. 397, 253-268, doi:10.3354/meps08317.

61. Sherman, K., Belkin, I., Friedland, K.D., O'Reilly, J. \& Hyde, K. (2009). Accelerated warming and emergent trends in fisheries biomass yields of the world's Large Marine Ecosystems. In: [25], pp. 41-79.

62. Perry, A.L., Low, P.J., Ellis, J.R. \& Reynolds, J.D. (2005). Climate change and distribution shifts in marine fishes. Science 308: 1912-1915.

63. Fisher, J.A.D., Frank, K.T., Petrie, B., Leggett, W.C. and Shackell, N.L. (2008). Temporal dynamics within a contemporary latitudinal diversity gradient. Ecol. Lett. 11: 883-897. doi:10.1111/j.1461-0248.2008.01216.x.
64. Worm, B., Hilborn, R., Baum, J.K., Branch, T.A., Collie, J.S., Costello, C., Fogarty, M.J., Fulton, E.A., Hutchings, J.A., Jennings, S., Jensen, O.P., Lotze, H.K., Mace, P.M., McClanahan, T.R., Minto, C., Palumbi, S.R., Parma, A.M., Ricard, D., Rosenberg, A.A., Watson, R. \& Zeller, D. (2009). Rebuilding global fisheries. Science 325: 578-585.

65. Snelgrove, P., Archambault, P., Juniper, K., Lawton, P., Metaxas, A., McKindsey, C., Pepin, P., Schneider, D. \& Tunnicliffe, V. (2008). Scientific criteria for conservation and sustainable usage of marine biodiversity in Canada, OCEANS 2008, 15-18 Sept. Page(s): 1 - 8. doi:10.1109/OCEANS.2008.5151889. 